\title{
Characterization of the Corrosion Resistance of Composite Peened Aluminum
}

Malte L. Flachmann (D, Michael Seitz, Wilfried V. Liebig, and Kay A. Weidenmann

Submitted: 21 June 2021 / Revised: 26 September 2021 / Accepted: 6 November 2021 / Published online: 22 November 2021

\begin{abstract}
Composite peening offers the opportunity to introduce ceramic blasting particles into metallic base material. By embedding $\mathrm{Al}_{2} \mathrm{O}_{3}$ particles, mechanical properties of aluminum can be improved. However, those surface modifications might negatively impact corrosion resistance and thus shorten the lifetime of components. This study analyzes corrosion properties of peened aluminum in chloride solution via immersion, scanning electron microscopy and polarization. The data of observed microstructures indicate that peening accelerates corrosion and that intergranular corrosion is the main force of degradation in contrast with pitting corrosion of monolithic aluminum.
\end{abstract}

Keywords alumina, aluminum, composite peening, corrosion resistance, immersion test, polarization

\section{Introduction}

Micro shot peening modifies surfaces by introducing residual compressive stress in near-surface regions. Ando et al. (Ref 1) observed that particles can also get stuck in the surface of the material during peening. Seitz et al. (Ref 2,3) showed that the depth of penetration can be influenced by heating of the peened specimen, one parameter among others. Control of the penetration depth is important as embedded particles may act as reinforcement of the surface regions. These regions form a hillvalley profile on the surface, as shown previously for EN AW1050 alloy (Ref 3) and EN AW-6082 alloy (Ref 4) with the embedded particles being detected in dimples in the valleys. Composite peening creates significantly rougher surfaces, which can be smoothened by subsequent deep rolling (Ref 5). Underneath the composite peened surface of alumina is a thin layer of magnesium aluminate $\mathrm{MgAl}_{2} \mathrm{O}_{4}$ (spinel), which is formed during the peening process (Ref 4). This spinel formation has also been observed on other interfaces of $\mathrm{Al}$ and $\mathrm{Al}_{2} \mathrm{O}_{3}$ (Ref 6,7), and spinel seems to be responsible for chemical bonding of alumina to the aluminum matrix, according to Levi et al. (Ref 8).

Corrosion describes the degradative loss of material and function due to the interaction with the environment (Ref 9). Aluminum is generally known for its good corrosion resistance due to its passive surface layer of $\mathrm{Al}_{2} \mathrm{O}_{3} \cdot \mathrm{Al}_{2} \mathrm{O}_{3}$-particles-

Malte L. Flachmann, Michael Seitz, and Wilfried V. Liebig, Karlsruhe Institute of Technology (KIT), Institute for Applied Materials (IAM-WK), Engelbert-Arnold-Straße 4, 76131 Karlsruhe, Germany; and Kay A. Weidenmann, Augsburg University, Institute of Material Resource Management, Universitätsstraße 1, 86159 Augsburg, Germany. Contact e-mail: michael.seitz@kit.edu.

embedded aluminum surfaces can be manufactured via the composite peening process. However, surface modifications like composites and coatings might impact corrosion, which occurs as both pitting and intergranular corrosion.

Knowledge on corrosion of aluminum-based metal matrix composites (MMC) with discontinuous reinforcement has been compiled by Bobic et al. (Ref 10). They recognized that pitting corrosion occurs at the fiber-matrix interface. The galvanic coupling of $\mathrm{Al}$ and $\mathrm{Al}_{2} \mathrm{O}_{3}$, however, does not worsen corrosion.

For corrosion protection, surfaces can be coated with layers up to hundreds of micrometers thick. The composite peening layer may act as a surface coating similar to cold gas spray (CGS) coating or anodized surfaces of alumina. The achieved corrosion resistances depend mainly on low porosity and thickness of the individual coatings, as analyzed for CGS coatings (Ref 11) and for anodized aluminum (Ref 12). The latter has an oxide layer of $5 \mu \mathrm{m}$ up to $150 \mu \mathrm{m}$, which needs to be sealed with low porosity (Ref 13). Algahtani et al. (Ref 12) improved the corrosion resistance with various ceramic coatings on EN AW-6082-T6 aluminum alloy surfaces. Density, uniformity and adherence are common key parameters of all coatings: the higher these parameters, the higher the achieved resistance.

$\mathrm{MgAl}_{2} \mathrm{O}_{4}$ has high chemical resistance that promotes corrosion resistance due to its layer continuity (Ref 14, 15). Dikici et al. (Ref 15) demonstrated that better protection is dependent on continuous layers, whereas $\mathrm{MgAl}_{2} \mathrm{O}_{4}$ in discontinuous layers has an opposite detrimental effect on aluminum corrosion. Corrosion via the pit formation spreads along the reinforcement interface but occurred preferentially in its vicinity, according to Lucas and Clarke (Ref 14). No evidence was found that corrosion preferentially starts at the $\mathrm{MgAl}_{2} \mathrm{O}_{4}$ interface layer.

The appearance of the composite peened surface provides an intermediate stage between MMCs and coatings. Therefore, this work analyzes the composite peened aluminum surface for its corrosion type and corrosion resistance, which is of crucial importance for the material's lifetime in a corrosive environment. 


\section{Experimental}

\subsection{Material}

The base material is a $2-\mathrm{mm}$-thick flat rolled sheet made of aluminum alloy EN AW-6082 (BIKAR-METALLE-Bad Berleburg, Germany); its chemical composition is depicted in Table 1 .

Ceramic particles of alumina of F600 microgrit (Arteka, Backnang-Waldrems, Germany) with a weight-averaged grain size of $9.3 \mu \mathrm{m} \pm 1.0 \mu \mathrm{m}$, angular shape and median particle size of $10 \mu \mathrm{m} \pm 2 \mu \mathrm{m}$ are used for blasting and as reinforcing material.

\subsection{Composite Peening}

Composite peening combines the micro shot peening process with additional heating of the base material to introduce ceramic particles into the surface. The composite peened surface is macroscopically uniform but forms microscopically a hill-valley profile with uneven thickness of the coating. The remaining $\mathrm{Al}_{2} \mathrm{O}_{3}$-particles are located in dimples on the aluminum surface, while the precipitations of the alloy are indicated by white particles (Fig. 1). The composite peening setup is described in detail by Seitz et al. (Ref 3). Specimens are manufactured at a homologous temperature $T / T_{\mathrm{s}}=0.9$ of aluminum, namely $490^{\circ} \mathrm{C}$. Slow cooling leaves no residual stress after the peening (Ref 16). The micro shot peening system is operated with a pressure of 7 bar, a nozzle of $0.76 \mathrm{~mm}$ in diameter, a working distance of $10 \mathrm{~mm}$ and a feed rate of $8 \mathrm{~mm} / \mathrm{s}$. A fourfold coverage with a path distance of $1 \mathrm{~mm}$ is used.

\subsection{Deep Rolling}

To modify near-surface parameters, deep rolling is applied with a pressure of $40 \mathrm{bar}$, a feed rate of $2000 \mathrm{~mm} / \mathrm{min}$ and trajectories spaced by $0.04 \mathrm{~mm}$ from each other. Deep rolling introduces residual compressive stresses of up to $-260 \mathrm{MPa}$ into the near-surface regions (Ref 16). Deep rolling reduces the surface roughness from $\mathrm{R}_{\mathrm{Z}}=13.7 \mu \mathrm{m} \pm 2.0 \mu \mathrm{m}$ after composite peening to $3.6 \mu \mathrm{m} \pm 1.4 \mu \mathrm{m}$, while the original roughness is $2.6 \mu \mathrm{m} \pm 0.4 \mu \mathrm{m}$ (Ref 4). Although the surface is more uniform, it is still crossed by valleys. The coating is uneven in thickness but without cracks.

\subsection{States of Aluminum Material}

Four states are compared in various experiments: (i) untreated aluminum, (ii) deep rolled aluminum, (iii) composite peened aluminum and (iv) composite peened and subsequently deep rolled aluminum. All the specimens are heat treated to T6 by soft annealing at $540^{\circ} \mathrm{C}$, quenched and aged for $6 \mathrm{~h}$ at $180^{\circ} \mathrm{C}$. The heat treatment is necessary to create comparability of the unpeened and peened specimens. The composite peening is done prior to and deep rolling is done after the heat treatment.

\subsection{Immersion Test}

An immersion test, described by Materialprüfanstalt Darmstadt MPA (Ref 17, 18), is applied to evaluate both the corrosion on this alloy and the surface modifications of the composite peening. The solution for this accelerated corrosion test contains the following chemicals and is summarized in Table 2.

Rectangular specimens $(11 \mathrm{~mm} \times 9 \mathrm{~mm} \times 2 \mathrm{~mm})$ are cut, cleaned with ethanol in an ultrasonic bath to remove dust and loose particles, weighed with Mettler Toledo ME-T analytical balance (Columbus, Ohio) and immersed in the test solution at $21^{\circ} \mathrm{C}$ for 120 minutes. After $5 \mathrm{~min}, 15 \mathrm{~min}, 45 \mathrm{~min}$ and at the end of exposure after $120 \mathrm{~min}$, they are cleaned in ultrasonic bath with deionized water and weighed again. Morphology and depth of the pits are examined by using a $\mu$ surf-type confocal microscope by NanoFocus (Oberhausen, Germany). All the specimens are also analyzed macroscopically and in representative cross sections by scanning electron microscope (SEM). The cross sections are analyzed for the surface morphology, pitting depth and intergranular corrosion.

The preparation of the cross sections is challenging due to differences in hardness between the base material and the reinforcement with alumina. A procedure according to Seitz et al. (Ref 19) is used, which applies low load for grinding and polishing to avoid both increased material removal of the matrix and relief formation.

\subsection{Potentiodynamic Polarization}

For electrochemical measurements on the material, a potentiodynamic polarization is conducted in $0.5 \%$ sodium chloride solution by polarizing with a platinum electrode and measuring with an $\mathrm{Ag} / \mathrm{AgCl}$-reference electrode. Specimens of $9 \mathrm{~mm} \times 7.5 \mathrm{~mm}$ are mounted in a 3D-printed custom-made electrode holder of polylactide (PLA) and clamped into a corrosion cell. Specimens equilibrate for one hour prior to measuring their corrosion potential $\left(E_{\mathrm{CORR}}\right)$ and initiating the scan of $\pm 200 \mathrm{mV}$ around $E_{\mathrm{CORR}}$ with $2 \mathrm{mV} / \mathrm{s}$. Calculations of $E_{\mathrm{CORR}}$ and corrosion rates are performed according to ASTM G102 (Ref 20).

\section{Results}

\subsection{Corroded Surface Structure}

All four states of the EN AW-6082 alloy are immersed in corrosive solution for $2 \mathrm{~h}$. Figure 2 shows representative macroscopic images of the surfaces after immersion. Both unpeened $\mathrm{Al}$ specimens show similar attacks of pit corrosion as shown in Figure 2(a) and Figure 2(b). Their surfaces are less shiny due to superficial corrosion. The composite peened specimens, as shown in Figure 2(c) and Figure 2(d), appeared uncorroded at a first glance, after being cleaned with water.

Table 1 Chemical composition of the EN AW-6082 alloy used based on measurements of spark spectroscopy

\begin{tabular}{lcccccccc}
\hline EN AW-6082 & Al & Si & Fe & Cu & Mn & Mg & Zn & Ti \\
\hline wt.\% & 97.15/Base & 0,88 & 0.40 & 0.08 & 0,43 & 0,90 & 0,09 & 0,03 \\
\hline
\end{tabular}




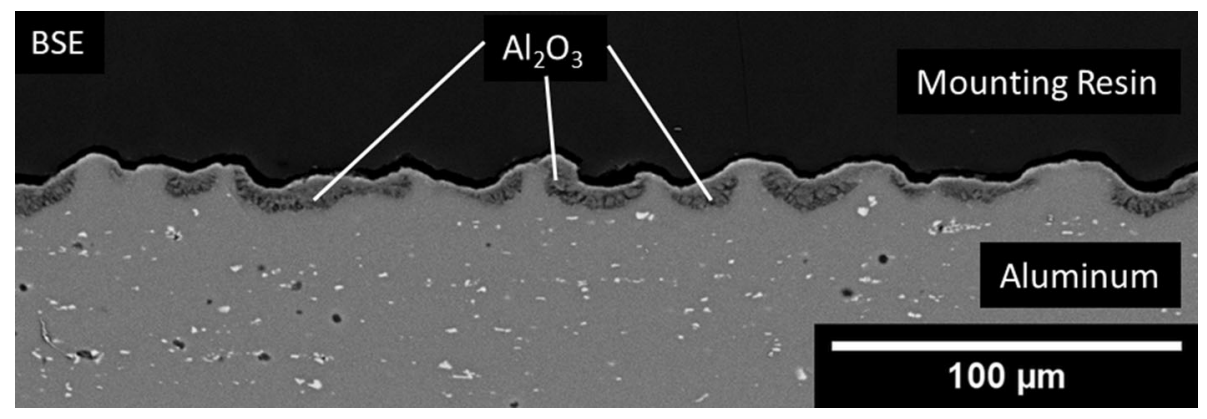

Fig. 1 Backscattered electron (BSE) image, cross section of the composite peened surface with alumina in dimples on the aluminum surface and precipitations in the aluminum alloy (particles in white)

Table 2 Chemical composition of the corrosion solution (Ref 17, 18)

\begin{tabular}{lccccc}
\hline Chemical & $\mathbf{M g C l}_{2} \cdot 6 \mathrm{H}_{2} \mathbf{O}$ & $\mathbf{C a C l}_{2} \cdot 2 \mathrm{H}_{\mathbf{2}} \mathbf{O}$ & $\mathbf{N a C l}$ & Deionized Water & HCl (25 \%) \\
\hline Quantity & $11.6 \mathrm{~g}$ & $8.4 \mathrm{~g}$ & $6.6 \mathrm{~g}$ & $1000 \mathrm{ml}$ & $100 \mathrm{ml}$ \\
\hline
\end{tabular}
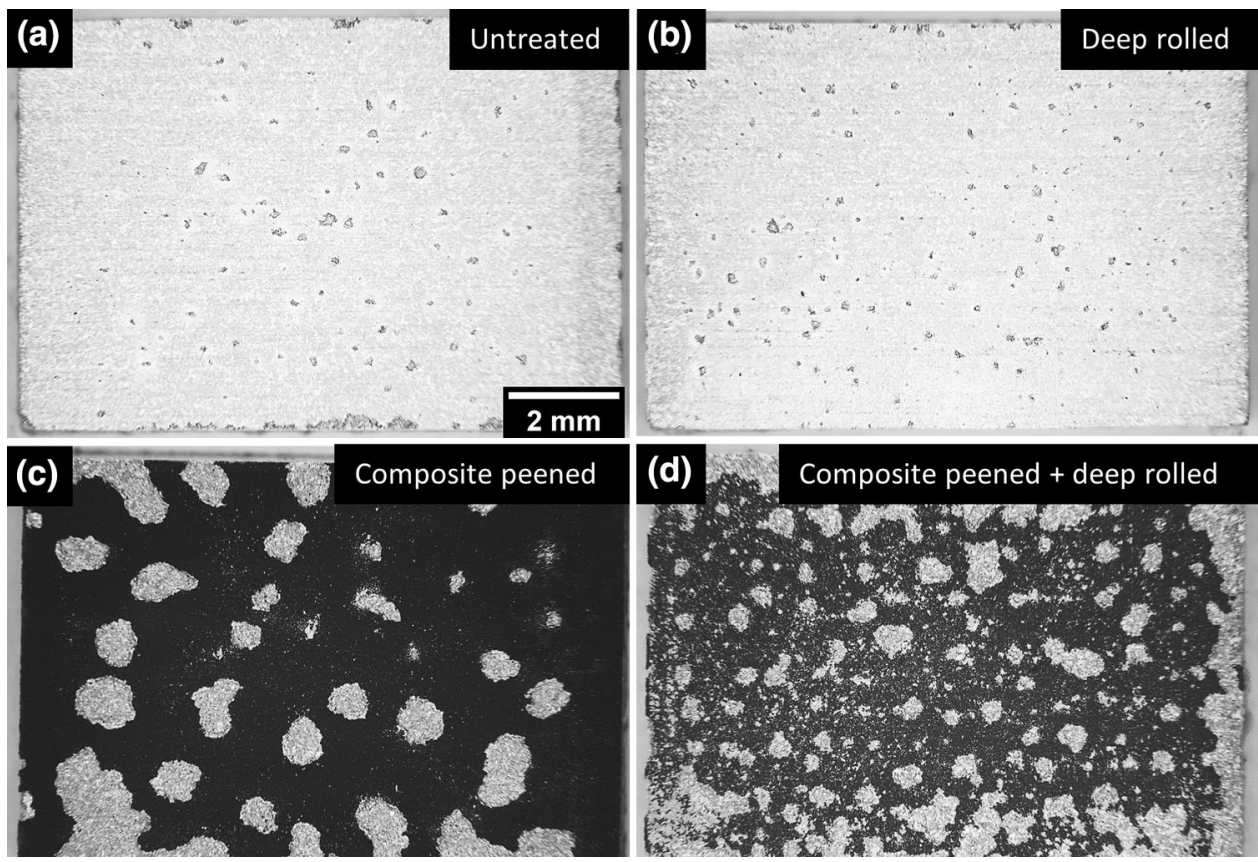

Fig. 2 Surface of corroded specimens after $2 \mathrm{~h}$ in corrosive solution. (a) Untreated $\mathrm{Al}$, (b) deep rolled $\mathrm{Al}$, (c) composite peened $\mathrm{Al}$ and (d) composite peened and deep rolled Al. Images taken via light macroscope

Ultrasonic cleaning after immersion revealed a large extent of corrosion. The composite peened aluminum in Figure 2(c) is affected by only a few pits, which are about tenfold larger in diameter (up to $2 \mathrm{~mm}$ ) than those of $0.25 \mathrm{~mm}$ in the unpeened specimens in Figure 2(a) and Figure 2(b). The surface of the composite peened and subsequently deep rolled specimen lightens up during the corrosion, as shown in Figure 2(d). Pits in this specimen are frequent but smaller compared to the composite peened specimen but significantly larger than in aluminum specimen.
Corroded surfaces were studied in more detail by backscattered electron microscopy (BSE). Comparatively small pits of less than $300 \mu \mathrm{m}$ in diameter are observed for the untreated states in Figure 3(a) and deep rolled state in Figure 3(b). Both composite peened specimens show pits larger than in the image sections of Figure 3(c) and (d).

Surfaces outside the pits show almost no corrosive damage. However, a crack-like structure is present on the entire surface of all the specimens, which seems to be indicative of intergranular corrosion. 

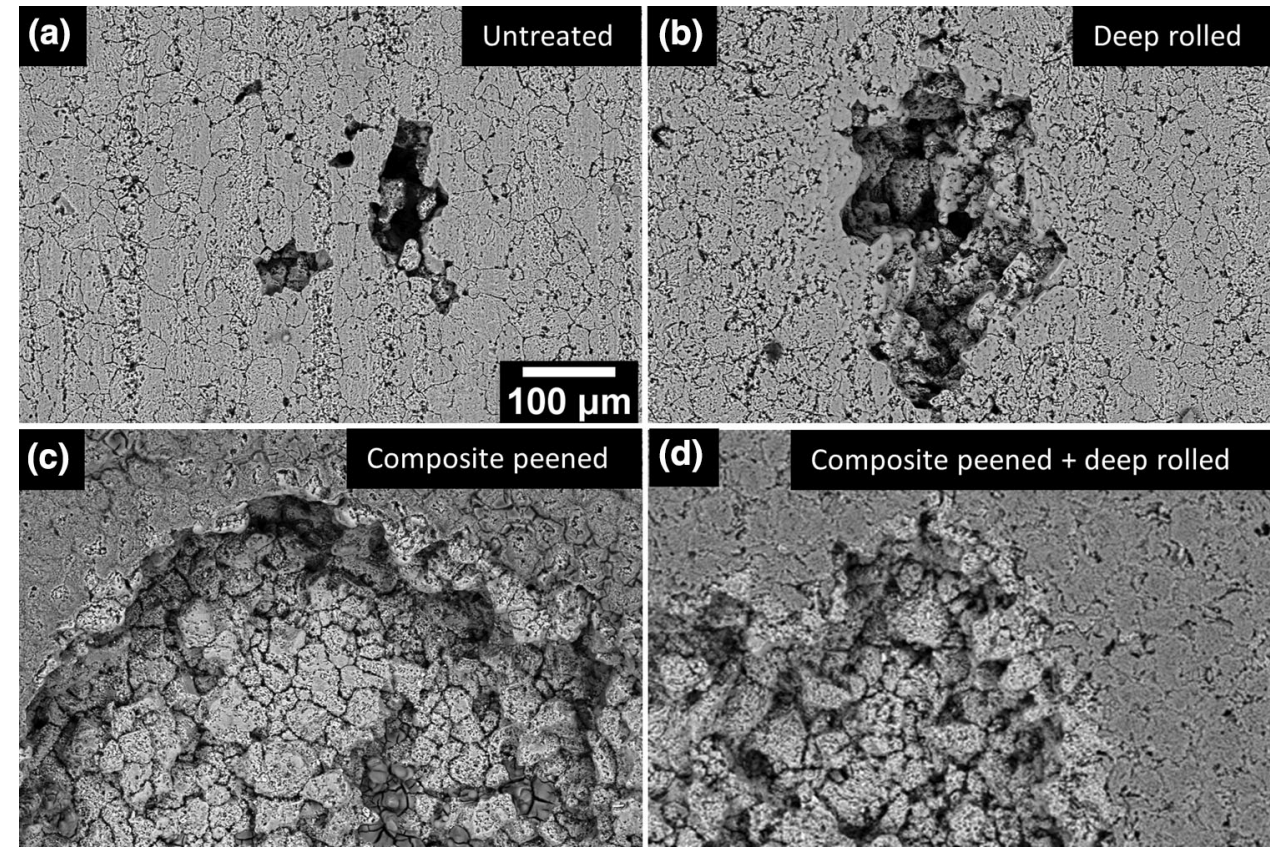

Fig. 3 BSE images of representative corroded surfaces of (a) untreated Al, (b) deep rolled Al, (c) composite peened Al and (d) composite peened and deep rolled $\mathrm{Al}$ after $2 \mathrm{~h}$ in corrosive solution

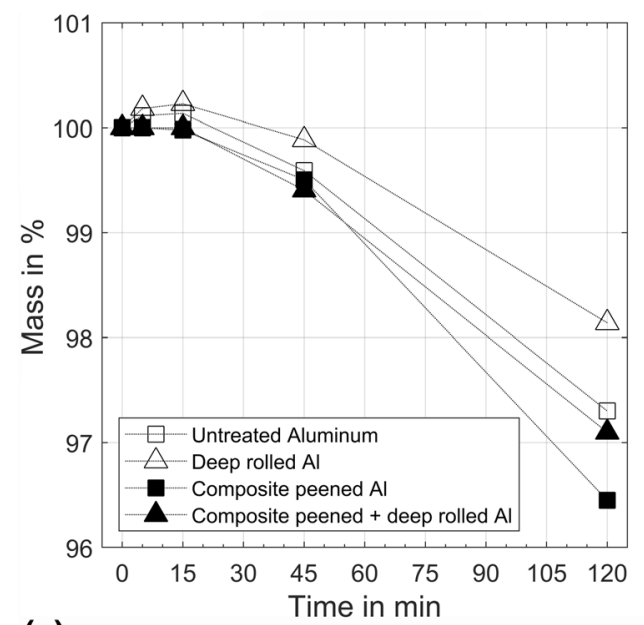

(a) Mass loss

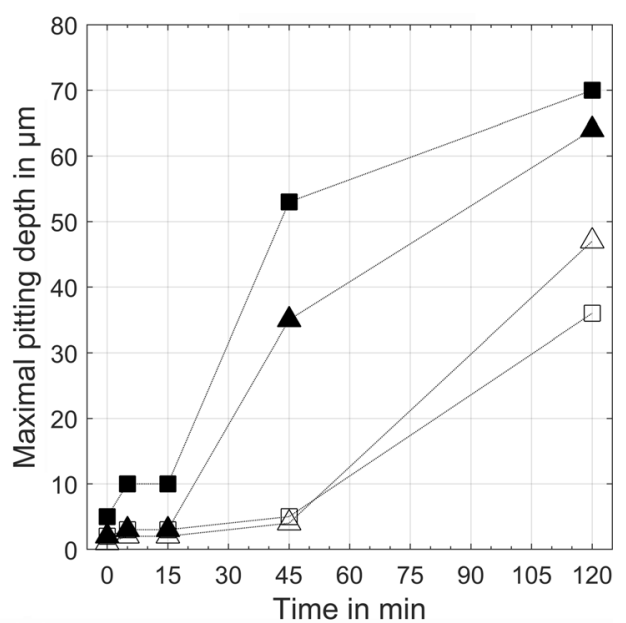

(b)Pitting depth

Fig. 4 Loss of mass (a) and pitting depth (b) within $2 \mathrm{~h}$ in corrosive solution

\subsection{Pitting Corrosion}

Corrosion can be quantified by measuring the loss of mass as shown in Fig. 4. There is hardly any loss of mass during the first 15 minutes, while after 45 minutes a minor loss of mass is detectable for all the specimens. The deep rolled state remains basically unchanged. After 120 minutes, the composite peened states lost $1 \%$ more mass than their corresponding unpeened specimens. Pits reach by then a maximum depth with up to $70 \mu \mathrm{m}$. Generally, the composite peened specimens show $20 \mu \mathrm{m}-30 \mu \mathrm{m}$ deeper pits than the unpeened specimens. Thus, higher loss in mass coincides with deeper pit corrosion.

\subsection{Intergranular Corrosion}

BSE analyses uncover strong intergranular corrosion in all specimens. Figure 5 shows a representative cross section of all states and a large image of the composite peened specimen. The depth of this intergranular corrosion differs in the four states. The untreated monolithic aluminum shows localized attacks up to $100 \mu \mathrm{m}$ in depth and the deep rolled specimen up to $160 \mu \mathrm{m}$ in depth. Both composite peened states are more extensively affected: the only peened specimen with up to $160 \mu \mathrm{m}(60 \%$ deeper than untreated aluminum) and subsequently deep rolled specimens with up to $200 \mu \mathrm{m}(25 \%$ deeper than in the 


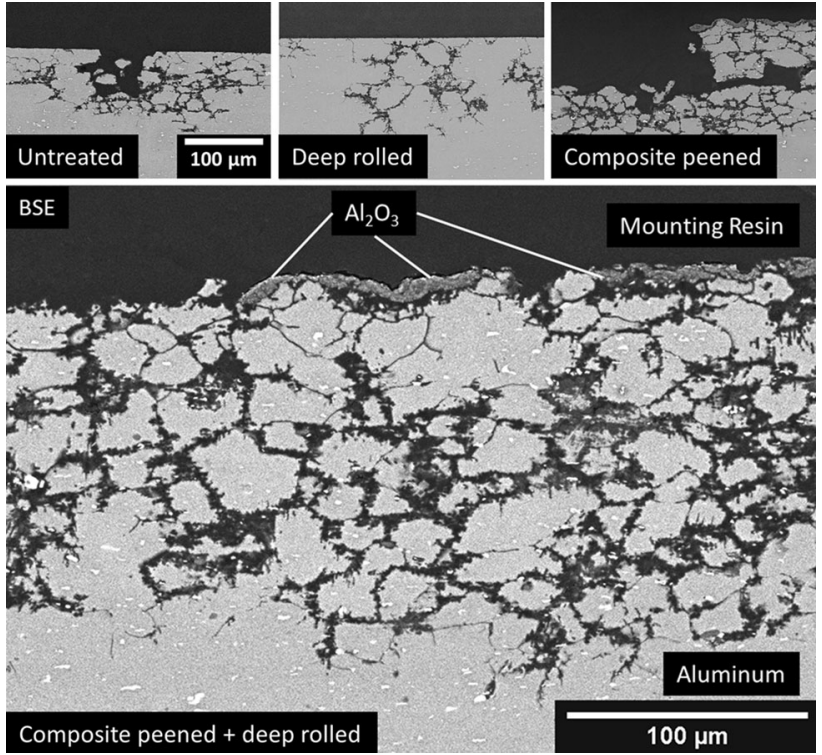

Fig. 5 Cross section of the four specimens (BSE image) after $2 \mathrm{~h}$ in corrosion solution. Intergranular corrosion forms a network beneath the surface

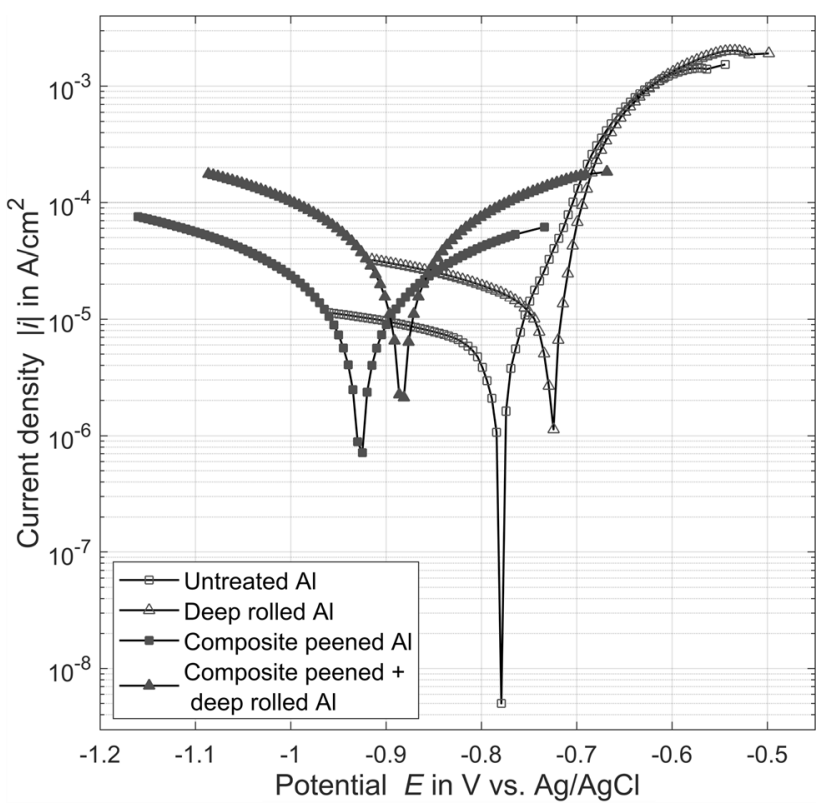

Fig. 6 Potentiodynamic polarization behavior of the four states in $\mathrm{NaCl}$ solution

corresponding state). The alumina layer is detached due to intergranular corrosion with a grain-like structure beneath the surface. The corrosion occurs at the weakest regions, like cracks, hills and thin areas and forms a network with a depth of up to $200 \mu \mathrm{m}$ approximately. Pits were only found with surrounding intergranular attack.

\subsection{Polarization Curves}

Potentiodynamic polarization curves are measured to determine the corrosion resistance of the four stages. Due to the geometry of the specimens, commercially available specimen holders cannot be used, and therefore, a customized specimen holder is additively manufactured. It was difficult to design a holder for long-lasting tightness in all the experiments. Therefore, several analyses are performed to obtain results without short circuit. Figure 6 shows the recorded potentiodynamic polarization curves, which have the following aspects in common. Firstly, the order for $E_{\mathrm{CORR}}$ (untreated with the most negative and composite peened/deep rolled AI with the least negative potential, see Fig. 6) is identical. Secondly, the composite peened specimens are shifted to higher negative values than the nobler $\mathrm{Al}$ specimens $\left(E_{\mathrm{CORR}}\right.$ of $-0.924 \mathrm{~V}$ for the composite peened specimen versus $-0.779 \mathrm{~V}$ for the substrate). Thirdly, the deep rolled states have less negative $E_{\mathrm{CORR}}$ than the corresponding states. Lastly, $i_{\mathrm{CORR}}$ values are lower for both untreated AI and composite peened AI than for the corresponding deep rolled states. Calculated values for corrosion current density $\left(i_{\mathrm{CORR}}\right)$ and corrosion rate $(\mathrm{CR})$ are shown in Table 3 . In addition, a significantly steep slope on the anodic branch of the polarization curves is observed with unpeened specimens ascending more than a decade higher in current density before flattening. This is in contrast with the symmetrical branches of the peened specimens, which show no sign for pitting corrosion.

\section{Discussion}

Surfaces of composite peened and unpeened aluminum are analyzed by scanning electron microscopy and by potentiometry in corrosive solution, as it is generally known that monolithic aluminum alloys suffer from pitting corrosion in chloride solutions (Ref 21, 22). Surface corrosion happens in untreated, as described previously, and deep rolled specimens (this study). Indicators are the steep anodic polarization branches, obvious pits and the visible disappearance of the shiny metallic surface in acidic corrosive solution. The solution triggers pitting corrosion with superimposed intergranular corrosion (Ref 18). The localized intergranular corrosion occurs while the passive oxide layer on the surface is almost unaffected. Corrosion can only occur at a few localized points where the structure is weakened.

Composite peening of the aluminum surface does not improve the resistance against corrosion, as demonstrated in this study, but these composite peened specimens corrode in a different way. Specimens seem to suffer only from intergranular corrosion since the presence of pits is only observed after ultrasonication, which causes the removal of the pit material. Intergranular corrosion is not typical for EN AW-6082 alloy with a mole ratio of $\mathrm{Mg}$ to Si higher than 1.73 (Ref 11), but it occurs at ratios below 1.73 with silicon surplus (Ref 23). The investigated specimens have a ratio of 1.0 at which intergranular corrosion is likely to occur as found by Bauer et al. (Ref 17) and as demonstrated in this study.

An extensive structure of intergranular corrosion is located directly underneath the alumina dimples. The stronger corrosion reaction of the composite peened specimens may include either the formed spinel $\left(\mathrm{MgAl}_{2} \mathrm{O}_{4}\right)$ or the magnesium-impoverished areas around spinel or both. The entire peened surface is evenly covered by the hill-valley structure in which the hills and valleys represent many structural weaknesses for corrosion initiations. Starting either at the aluminum surface or at contact points of aluminum and alumina, the intergranular corrosion spreads out deep into the material. A network of cracks below 
Table 3 Corrosion potential $E_{\mathrm{CORR}}$, corrosion current density $i_{\mathrm{CORR}}$ and corrosion rate CR of specimens

\begin{tabular}{lcccc}
\hline & Untreated Al & Deep rolled Al & Composite peened Al & Composite peened + deep rolled Al \\
\hline $\mathrm{E}_{\mathrm{CORR}}$ in $\mathrm{V}$ & -0.779 & -0.724 & -0.924 & -0.881 \\
$\mathrm{i}_{\mathrm{CORR}}$ in $\mathrm{A} / \mathrm{cm}^{2}$ & $3.39 \cdot 10^{-6}$ & $8.76 \cdot 10^{-6}$ & $3.94 \cdot 10^{-6}$ & $10.7 \cdot 10^{-6}$ \\
$\mathrm{CR}$ in $\mathrm{mm} / \mathrm{a}$ & 0.0370 & 0.0956 & 0.0430 & 0.1168 \\
\hline
\end{tabular}

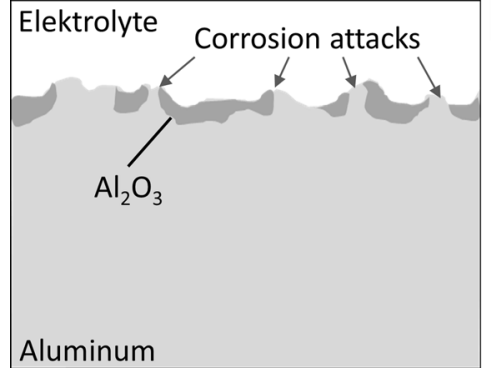

(a)

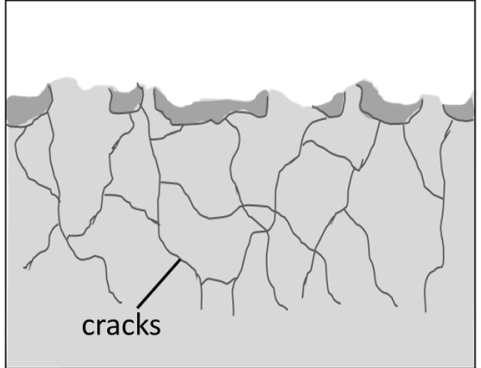

(b)

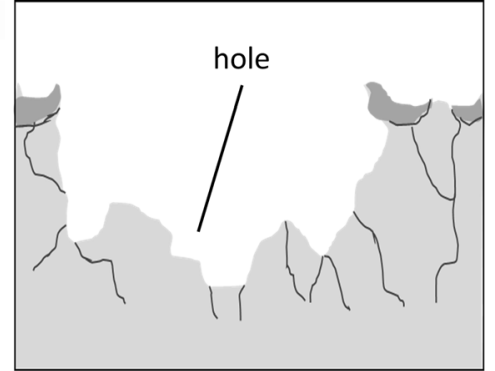

(c)

Fig. 7 Scheme of hole formation: (a) corrosion attacks at structural weaknesses, (b) cracks form at grain boundaries by advanced corrosion, (c) removal of loose particles creates hole

the surface weakens and loosens large areas and this material can be detached and removed by ultrasonication, as illustrated in Fig. 7. This mechanical removal by sonication seems to be the most likely explanation for the observed large pits as characteristics for pitting corrosion are missing.

This conclusion is supported by polarization data, which show no evidence for pitting corrosion as well.

Actually, in potentiodynamic polarization a more active corrosion potential is measured for peened specimens compared to the unpeened ones, again indicating higher corrosion and larger pits after peening.

This study leads to the assumption that changes in the type of corrosion are caused by the surface embedded ceramic particles. This phenomenon is so far unreported by other studies.

In comparison with other surface modifications, the composite peened specimens behave more like an MMC than a coated material. The thin uniform layer of alumina shows poor corrosion resistance as observed for segregated phases in MMCs by Yang and Metzger (Ref 24) and many others (Ref $10,22,25)$. In addition, the corrosion at $\mathrm{MgAl}_{2} \mathrm{O}_{4}$ promotes this effect due to enhanced silicon concentration underneath this thin layer ( $\operatorname{Ref} 23)$.

\section{Conclusions}

This study examined the previously uncharacterized corrosion behavior of composite peened aluminum. Data of independent analytical methods show that this surface modification of aluminum results generally in lower corrosion resistance compared to the untreated surface. Ceramic microparticles in the surface of composite peened aluminum cause predominantly intergranular corrosion compared to pitting corrosion of monolithic aluminum. This intergranular corrosion is caused by both structural weaknesses and the interface between the $\mathrm{Al}_{2} \mathrm{O}_{3}$-reinforcement and the matrix of the composite peened layer. The corroded reinforced surface has both larger and deeper pits and detaches compared to the aluminum surface. The lower corrosion resistance cannot be improved by surface flattening via deep rolling of composite peened aluminum and thus needs attention for the material application in corrosive environments.

\section{Acknowledgment}

The authors would like to thank the German Research Foundation (DFG) for the financial support within the project WE4273/15-1. This work was partly carried out with the support of the department Materials and Processes of the Institute for Applied Materials (IAM-WK) at the Karlsruher Institute of Technology (KIT). Additionally, we thank Markus Muth and Anselm Heuer for additively manufacturing the working electrode. Further we thank Dr. Andreas Hofmann (IAM-WK) for providing the potentiostat.

\section{Open Access}

This article is licensed under a Creative Commons Attribution 4.0 International License, which permits use, sharing, adaptation, distribution and reproduction in any medium or format, as long as you give appropriate credit to the original author(s) and the source, provide a link to the Creative Commons licence, and indicate if changes were made. The images or other third party material in this article are included in the article's Creative Commons licence, unless indicated otherwise in a credit line to the material. If material is not included in the article's Creative Commons licence and your intended use is not permitted by statutory regulation or exceeds the permitted use, you will need to obtain permission directly from the copyright holder. To view a copy of this licence, visit http://creativecommons.org/licenses/by/4.0/.

\section{Funding}

Open Access funding enabled and organized by Projekt DEAL. 


\section{References}

1. M. Ando, H. Kitano, H. Usami and T. Endo, Applicability of Fine Particle Peening on Surface Modification of Aluminum Alloy. In: The 10th International Conference on Shot Peening procedure. 2008:223-7

2. Seitz M., Influence of the Process Parameters on the Penetration Behaviour of Ceramic Particles in Composite Peening. In: Symposium Mechanical Surface Treatment 2019: 8th Workshop Machine Hammer Peening, Karlsruhe, 22 and 23 October 2019; 2019, pp. 85-99. https://d oi.org/10.5445/IR/1000099108

3. M. Seitz and K.A. Weidenmann, Influence of the Process Parameters on the Penetration Depth of the Reinforcing Phase During Composite Peening for the Production of Functionally Graded Metal Matrix Composites. Key Eng. Mater., 2019; 809: 73-8. https://doi.org/10.40 28/www.scientific.net/KEM.809.73

4. M. Seitz, M. Dürrschnabel, A. Kauffmann, C. Kurpiers, C. Greiner and K.A. Weidenmann, Characterization of the Microstructure After Composite Peening of Aluminum, Adv. Eng. Mater., 2020 https://doi. org/10.1002/adem.202000575

5. M. Seitz, K.A. Weidenmann, Mechanical investigations on composite peened Aluminium. In: S. Itoh, S. Shukla editors. Advanced Surface Enhancement. Singapore: Springer Singapore; 2020, pp. 10-18. http s://doi.org/10.1007/978-981-15-0054-1_2. 978-981-15-0053-4

6. A.C. McLeod and C.M. Gabryel, Kinetics of the Growth of Spinel, MgAl2O4 on Alumina Particulate in Aluminum Alloys Containing Magnesium, Metall. Trans. A, 1992, 23, p 1279-1283. https://doi.org/ 10.1007/BF02665059

7. T.P.D. Rajan, R.M. Pillai and B.C. Pai, Reinforcement Coatings and Interfaces in Aluminium Metal Matrix Composites, J. Mater. Sci., 1998, 33, p 3491-3503. https://doi.org/10.1023/A:1004674822751

8. M. Metzger and S.G. Fishman, Corrosion of Aluminum-Matrix Composites. Status report, Ind. Eng. Chem. Prod. Res. Dev., 1983, 22(2), p 296-302. https://doi.org/10.1021/i300010a026

9. S.M. Hassani-Gangaraj, A. Moridi and M. Guagliano, Critical Review of Corrosion Protection by Cold Spray Coatings, Surf. Eng., 2015, 31(11), p 803-815. https://doi.org/10.1179/1743294415Y.0000000018

10. B. Bobic, S. Mitrovic, M. Babic and I. Bobic, Corrosion of Metalmatrix Composites with Aluminium Alloy Substrate, Tribol. Ind., 2010, 32(1), p 3-11

11. F.S. Da Silva, N. Cinca, S. Dosta, I.G. Cano, J.M. Guilemany and A.V. Benedetti, Cold Gas Spray Coatings Basic Principles Corrosion Protection and Applications, Eclet. Quim. J., 2017, 42(1), p 9. http s://doi.org/10.26850/1678-4618eqj.v42.1.2017.p09-32

12. A. Algahtani, E. Mahmoud, S. Khan and V. Tirth, Experimental Studies on Corrosion Behavior of Ceramic Surface Coating Using Different Deposition Techniques on 6082-T6 Aluminum Alloy, Processes, 2018 https://doi.org/10.3390/pr6120240

13. Y. Zuo, P.-H. Zhao and J.-M. Zhao, The Influences of Sealing Methods on Corrosion Behaviour of Anodized Aluminum Alloys in $\mathrm{NaCl}$ Solutions, Surf. Coat. Technol., 2003, 166, p 237-242. https://doi.org/ 10.1016/S0257-8972(02)00779-X
14. K.A. Lucas, H. Clarke, Corrosion of Aluminium-based Metal Matrix Composites, Research Studies Press LTD, Taunton, Somerset, England, 1993

15. B. Dikici, M. Gavgali and C. Tekmen, Corrosion Behavior of an Artificially Aged (T6) Al-Si-Mg-based metal matrix composite, $J$. Compos. Mater, 2006, 40(14), p 1259-1269. https://doi.org/10.1177/ 0021998305057434

16. M. Seitz, Bewertung der Prozess-Struktur-Eigenschaftsbeziehung von verbundgestrahlten Aluminiumwerkstoffen [Dissertation]. Karlsruher Institut für Technology, Karlsruhe, 2021

17. K. Bauer, L. Yu, H. Hanselka and M. Oechsner, Zuverlässige Qualifizierung von Aluminiumwerkstoffen für Fahrwerksbauteile, ATZ-Automobiltechnische Zeitschrift, 2012, 114, p 1004-1010. http s://doi.org/10.1007/s35148-012-0519-4

18. T. Troßmann, L. Yu, K. Bauer, H. Kaufmann and J. Grimm, Aluminium Alloys Exposed to Borderline Solutions - a methodology to evaluate the susceptibility to corrosion fatigue with respect to corrosive de-icers, Mat.-wiss. u. Werkstofftech., 2011, 42(10), p 921928. https://doi.org/10.1002/mawe.201100870

19. M. Seitz, L. Karch and K.A. Weidenmann, Preparation Methods for Electron-Scanning and Light-microscopic Analysis of Composite Peened Aluminium-Alumina Particle Composites, Pract. Metallogr. 2020, 57(8), p 536-544. https://doi.org/10.3139/147.110635

20. ASTM G102.17287: Practice for Calculation of Corrosion Rates and Related Information from Electrochemical Measurements. West Conshohocken, PA: ASTM International. https://doi.org/10.1520/G010289R15E01. [2015]

21. Z.M. Gasem, A.M. Al-Qutub, Corrosion Behavior of Powder Metallurgy Aluminum Alloy 6061/A12O3 Metal Matrix Composites, 6th Saudi Engineering Conference KFUPM, 2008, Vol. 5, p 270280

22. P.C.R. Nunes and L.V. Ramanathan, Corrosion Behavior of Aluminaaluminum and Silicon Carbide-aluminum Metal-matrix Composites, Corrosion, 1995, 51(8), p 610-617. https://doi.org/10.5006/1.3293621

23. F.-L. Zeng, Z.-L. Wei, J.-F. Li, C.-X. Li, X. Tan, Z. Zhang and Z.-Q. Zheng, Corrosion Mechanism Associated with Mg2Si and Si Particles in Al-Mg-Si Alloys, Trans. Nonferrous Metals Soc. China, 2011, 21(12), p 2559-2567. https://doi.org/10.1016/S1003-6326(11)6 1092-3

24. J.-Y. Yang, M. Metzger, Relation Between Pitting and Structure in Experimental $\mathrm{Al}-\mathrm{Mg} / \mathrm{Al}_{2} \mathrm{O}_{3}$ Composites, In: Soc., editor. Extended abstracts/Electrochemical Society, New York, NY, Soc., 1981, pp. 389390

25. L. Bertolini, M.F. Brunella and S. Candiani, Corrosion Behavior of a Particulate Metal-matrix Composite, Corrosion J., 1999, 55(4), p 42231. https://doi.org/10.5006/1.3284003

Publisher's Note Springer Nature remains neutral with regard to jurisdictional claims in published maps and institutional affiliations. 